\title{
Viewpoint: Are grazing rights on public lands a form of private property?
}

\author{
LEIGH RAYMOND
}

Author is a research assistant and Ph.D. student, Department of Environmental Science, Policy, and Management, University of California at Berkeley, Berkeley, Calif. 94720.

Abstract

Some have argued that federal grazing preferences or permits are a form of private property and should be recognized as such by the federal government. This vlewpoint studies the grazing controversy from 2 perspectives; legal and theoretical. A strict analysis of statutes and case law reveals some ambiguity in the law, but little that clearly supports the private property rights argument. A second analysis of several more theoretical approaches to the issue reveals a stronger case for private property based on the idea of customary use, as embodied in certain interpretations of the public trust doctrine and other alternative views. Because the non-legal argument is much more persuasive, it should be utilized more frequently by private property advocates. Opponents of the private property argument should consider that simple legal victory is often an inadequate solution to conflicts such as the grazing rights controversy. Advocates on both sides, as well as range managers and others simply wanting a better understanding of the issue, should make an effort to view the controversy from both of the perspectives presented here. Failure to do so will likely result in more lawsuits, more damaging controversy, and a continued lack of resolution to the conflict.

Key Words: customary use, grazing permits, planning, property rights, public land, public trust doctrine

\begin{abstract}
"Seeing property is an act of imagination-and seeing property also reflects some of the cultural limitations on imagination. Different people see the signals of the surroundings through very different imaginative lenses, and they put those signals together in different property stories; they persuade themselves that the things they see can yield the security of entitlement, whatever that may entail, and then they act on the visible signals as if the signified entitlements were permanent, solid, objective. And to some degree they are-so long as everyone, or most everyone, is persuaded" (Rose 1994, p. 296).
\end{abstract}

In terms of the passage quoted above, there is no lack of imagination in the American West on the issue of grazing permits and property rights. Whether a grazing preference or permit (the 2 terms are different and will be distinguished shortly) is a form of protected private property is a strongly-contested issue in the courts and on the land itself with important consequences for land management. Most everyone, to paraphrase Rose, is not persuad-

\footnotetext{
Author wishes to thank John Dwyer, Sally K. Fairfax, Lynn Huntsinger, and 2 anonymous reviewers for comments regarding earlier versions of this essay. Author also wishes to thank Sally K. Fairfax for generous financial support related to publication of this research.

Manuscript accepted 11 Aug. 1996.
}

ed at all about what a grazing permit signifies. This article will review the public lands grazing dispute using several theories of property to shed light on the subject. For while there has been a great deal of anger and rhetoric about the grazing permit issue, there has been relatively little quiet analysis and review. Land managers, ranchers, and others affected by the subject would do well to consider all sides of the issue in a more dispassionate manner. This paper hopes to be a small step in that process of better understanding.

Starting within the legal system, this essay will review the arguments of "private rights in public lands" advocates as represented by Nevada rancher Wayne Hage and attorneys Frank Falen and Karen Budd-Falen. Discussion of their arguments will entail an analysis of many of the federal statutes, state and federal court cases, IRS rulings, and Supreme Court decisions involved. When this legal review is complete, we will see that the grazing permit exists in a limbo of sorts, legally short of being a "vested right" of property, but a "thing of value" nonetheless. Ultimately, however, there is little in the current case law and statutes to support the legal property claims of the private rights advocates.

This legal analysis only paints half the picture. For a complete view, one needs to turn to other scholars and bring their "imaginative lenses" to bear on the subject. The theories of John Locke as expressed in the common law; of "new property" as described by Charles Reich and applied by Robert Nelson; of norms and customs as described by Robert Ellickson, and of the public trust doctrine as described by Rose and Joseph Sax all bring new insights to the dispute. More importantly, they illustrate the importance of custom as a persuasive, non-legal justification for private grazing rights. Finally, the essay discusses Rose's idea of "Property as Persuasion" as the unifying theme of the investigation. Rose's observations regarding the fragility of a system of property in general indicate how important it is to resolve the current disagreement in a manner that is persuasive to all.

\section{"Private Rights in Public Lands"-The Legal Argument}

Rancher and advocate Wayne Hage $(1989$, p. 4) asserts his case clearly: "The federal government owns the federal lands, but it does not own range rights to the federal lands. The private rancher owns the range rights to the federal lands." Hage bases his position on 2 primary lines of thought. The first is that specific ranchers earned a right to forage on public lands through the venerable western doctrine of "first in time, first in right." Initial settlers of the west staked a claim to a base property and to the associated rangelands surrounding it. The fee-simple claim on the base property was made under one of the various homesteading acts and is recognized by the government. The claim to the sur- 
rounding range forage is based upon a preference right to graze those lands that stems from prior appropriation of the water and forage therein combined with a "customary occupancy of the range" (Hage 1989, p. 11). These rights were recognized by the Supreme Court, according to Hage, in the 1890 decision Buford v. Houtz (133 U.S. 320). In Buford, Hage claims that the court declared a license created for graziers on the federal lands with the full endorsement and encouragement of the federal government. "Many," he argues, "viewed [this decision] as a federal endorsement of preemption as a means of recognizing private title to the range" (Hage 1989, p. 90). The subsequent development of permit systems by the Forest Service and later the Grazing Service were essentially codifications of these preference rights to graze. Thus, the grazing permit is different from and dependent upon the pre-existing right to graze. "The granting of a permit did not create any rights," Hage (1989, p. 187) argues, "it acknowledged pre-existing rights. .." This distinction between a permit and an alleged underlying preference right is critical because of a long string of court cases that private rights advocates say find no property rights inherent in a grazing permit but remain silent on the issue of a preemptive or preference right to grazing (Falen and Budd-Falen 1993).

Hage (1989) cites 4 common transactions involving a grazing permit in support of his position. They are:

(1) grazing rights to public lands are attached to base properties and transfer with them under private sales;

(2) rights are therefore bought and sold from ranchers rather than the federal government;

(3) the military pays compensation to ranchers when taking permit land formerly used for grazing; and,

(4) the IRS includes the value of the grazing right in calculating estate and other taxes on ranch property.

These practices form a central part of many of the legal challenges to the "anti-property" views of government agencies. They will come up frequently in the legal cases discussed in this section.

Hage makes a second claim to grazing rights based on state and federal water law, and the doctrine of prior appropriation. Under this doctrine, water users in the arid west have a property right in the water they use (or "appropriate") from a local source. This right is based strictly on seniority of use, recognizing the first user as entitled to his or her full right before any other users may take their shares. Western water rights depend on a "beneficial use" of the water-one cannot simply divert water for no purpose to claim a water right. Grazing has been largely recognized as such a beneficial use and is therefore the key to retaining a rancher's water right. Loss of a beneficial use means loss of the appropriative right to those next in order of seniority. Thus, the belief in the west according to Hage $(1989$, p. 151) has been "he who owns the water owns the land." Furthermore, Hage (1989, p. 194) poses the following question: "If the stock water rights on the federal lands, established through livestock grazing as a proof of beneficial use are valid, how can the right to graze be invalid?" For Hage, the recognition of water rights as property under federal law necessitates a recognition of a property right in the accompanying beneficial use.

This is a basic outline of the argument for private property rights to graze on the public lands (henceforth referred to as simply the "private property" position or case). Further consideration of this argument requires a review of the actual legal history of the grazing permit question, to which this article will now turn.

\section{Private Grazing Rights-A Legal Review}

Any review of the grazing rights of ranchers must start (as Hage does) with the 1890 case Buford v. Houtz. In this case, a cattle rancher owning private land "checkerboarded" with public domain sections sued to prevent a nomadic sheep herder from grazing the rancher's private lands along with the public sections. The rancher was forced to seek legal remedy since he could not effectively fence his property without also enclosing the public domain, which would be illegal. The court showed the rancher little sympathy, finding that he was trying to monopolize the entire public-private tract through ownership of one-third the land. "The rights of all parties. . .is equal" to use the public domain (Buford, p. 326). Thus the court found against the plaintiff and for the shepherd.

This seems a strange case to claim victory for the rancher's right to graze public lands. But Hage (1989) cites a key passage from the decision. "We are of the opinion," the court declared, "that there is an implied license, growing out of the custom of nearly a hundred years, that the public lands of the United States. . . shall be free to the people who seek to use them where they are left open and unenclosed, and no act of government forbids this use. . No doubt. . .this has been done with the consent of all branches of the government, . . and with its direct encouragement" (Buford, p. 326). Hage (1989, p. 16) sees this finding and the term "implied license" as a recognition of the rancher's right to graze the range. Legally, of course, a license is essentially a permission to enter onto another's property without trespass-it is revocable without compensation and is not at all the same thing as a vested property right (Boyer et al., 1991, p. 317). Nevertheless, in Hage's view, the Buford decision left the rancher only a "step or two" away from fully private rights in public lands (Hage 1989, p. 16). Such a claim is hard to defend given the full facts of the case. The Buford court clearly concluded that the public lands are a type of open-access resource, free for all to use on an equal basis until otherwise announced by the government. By explicitly rejecting the argument for private ownership of public lands, the court anticipated and dismissed an argument for exclusive ownership similar to Hage's own position.

A trio of early twentieth century cases are key to further interpreting Hage's arguments. In 1911 the Supreme Court decided 2 cases back-to-back approving the right of the government to regulate or prohibit grazing on public lands-Light v. United States (220 U.S. 523) and United States v. Grimaud (220 U.S. 506). The Grimaud case ratified the authority of the fledgling U.S. Forest Service to promulgate regulations on its forest reserve lands. In Light (p. 535), the court tackled grazing rights head-on, reducing its tolerance of grazing on public lands by noting that the United States merely "suffered its public domain to be used for such purposes." This passive "failure to object" by the government did not give any "vested right" to the ranchers using the range, nor did it eliminate the federal power to "recall any implied license" for private use at any time. The third case provides an interesting twist on these themes. In Omaechevarria V. State of Idaho (246 U.S. 343 (1917)), the court ratified an Idaho statute excluding sheep from public rangelands traditionally grazed by cattle. By favoring the presence of cattle on the range, the decision could be seen as contrary to the reasoning in Buford. However, the court was careful to distinguish the two cases. The Idaho statute was enacted to "prevent breaches of the peace" between range users rather than provide any rights in public lands to specific citizens. The precedents of Buford and Light remained unchanged. 
The next chapter in the story is the 1934 Taylor Grazing Act (TGA). This statute was the first formal attempt by the government to regulate grazing in the public domain rather than just on the forest reserves under the Forest Service. The TGA appears to be an amalgamation of compromise language, written under pressure from all sides on the range controversy. In the first sentence, for example, the act is described as being in effect over the public domain only "pending [the land's] final disposal" (48 Stat. 1269). The TGA set up the now familiar grazing districts and fee-andpermit system, with a new federal Division of Grazing served by livestock advisory boards to regulate the range. Preferences for grazing permits were given to landowners with a history of use (in the preceding 5 years) of the rangelands in question. The act gave permittees a first-right of renewal "in the discretion of the Secretary of the Interior," and entitled them to payment or compensation from new permittees for range improvements if the permit changes hands. More importantly for Hage, the act explicitly protected pre-existing rights "under existing law" unless otherwise provided in the act itself. The act also explicitly protected existing water rights, another important part of Hage's case.

The key phrase in the act, however, comes at the end of Section Three. "So far as is consistent with the purposes and provisions of this Act," the law reads, "grazing privileges recognized and acknowledged shall be adequately safeguarded, but the creation of a grazing district or the issuance of a permit pursuant to the provisions of this Act shall not create any right, title, interest or estate in or to the land" (emphasis added). This statement has been an oft-cited reply against rancher claims of property rights ever since it was written into law 62 years ago. Hage has a response, however. His answer relies on the distinction between preference rights and grazing permits. As noted above, permits for Hage are merely a recognition of an already existing right of a rancher to graze these lands. Thus, the phrase in the TGA merely ratified that truth by declaring that no new rights in the range arise from mere grazing permits-in case some interloper gained such a permit and then thought he had an actual right to the range forage. "The [TGA] was specific," Hage (1989, p. 179) concludes, "in barring federal agents from creating their own clientele among graziers in the grazing districts by granting permits or including within a grazing district those stockmen without prior rights."

This is an interesting interpretation, and the statutory maintenance of prior claims by the act seems to add to the argument's credibility. A full reading of the act, however, as well as the cases reviewed above shows that Hage's view is ultimately hard to support. Buford and Light both indicate that the government recognized no special preference rights to grazing on public lands. The TGA itself is full of phrases declaring the ultimate authority of the government rather than the rancher to create, modify, or destroy these grazing rights. In Section 3, the Secretary is authorized to issue permits to "bona fide" settlers and ranchers "as under his rules and regulations are entitled to participate in the use of the range." In Section 7, the Secretary is authorized to "examine and classify" all grazing district lands and open them to other uses such as homesteading where he deems appropriate. In the U.S. Code referring to these issues, the Secretary is further authorized to lease additional land for grazing districts in order to "promote orderly use of the district and aid in conserving the forage resources of the public lands therein" (43 U.S.C. $\$ 315 \mathrm{~m}-1$ ). None of this language looks compatible with a recognition of existing private rights to graze, and the subsequent case law bears this observation out.

Four years after the TGA passed, the ranchers gained a significant victory in the courts in Red Canyon Sheep Co. V. Ickes (98 F.2d 308 (1938)). The case arose over a plan by the government to trade lands currently grazed under permit for other lands in order to consolidate holdings. The permittee, Red Canyon Sheep Co., sued to stop the trade, arguing that its private landholdings and improvements would become "valueless" without the permit lands leaving the owners unable to run their business. The $\underline{\text { Red }}$ Canyon Court entered into a lengthy discussion of the preceding legal history of range rights, concluding importantly that TGA grazing rights are not "vested rights in property." But the court did not end its discussion on this point-"Yet, whether they [the permits] be called rights, privileges, or bare licenses, or by whatever name, while they exist they are something of real value to the possessors and something which have their source in an enactment of the Congress" (Red Canyon, p. 315). The court also made an interesting comparison to water rights relevant to Hage's argument. A water right is a "vested interest" but "something less than the full ownership of property" because it is a right only to use the water (sometimes called a "usufructuary right"). The court made another analogy between the right to hunt on public lands and the right to graze there-"both are subject to restriction or withdrawal. . .yet both are of value to the persons possessing them" (Red Canyon, p. 316).

The interest of "real value" to the permittee merits legal protection, said the court, and it invalidates the trade of land. The court indicated that legal protection for permittees is only against the illegal acts of the government, however, in ruling that the transfer in question is prohibited by law. The court refrained from ruling on whether any such transfer would be illegal under justifications other than those presented, such as Section 7 of the TGA (see discussion above). Thus, the Red Canyon decision establishes that the grazing permit has sufficient value to a permittee to merit protection against illegal and unauthorized actions by the government. Protection of the permit against legal government actions (such as federal regulation of grazing allotments or withdrawal of permit lands) was not addressed by the case.

In 1963, however, the Federal Courts decided another case similar to Red Canyon. In this instance (LaRue v. Udall, 324 F.2d 428), a Nevada grazing permittee was threatened with loss of his permit due to a government transfer of the permit lands to a private defense contractor. The permittee argued that the TGA does not authorize such transfers of land when they will destroy a ranch business. He also made the argument that he had pledged his permits as collateral on a loan, and therefore could not have them revoked per Section 3 of the TGA. The court did not agree with either of these arguments, stating that the transfer was within the Secretary's rights and that the right to renewal of a grazing permit pledged as a loan is only a right against other potential permittees, not a "vested interest" in the land preventing government action. In this case, the legal government action of a land transfer was permitted to occur without compensation to the permittee.

The final and most recent case to deal with the private property nature of grazing permits came before the Supreme Court in 1972. U.S. V. Fuller (409 U.S. 488) was a condemnation action by the government of 920 acres of a range permittee's base property owned in fee-simple. The legal question was whether the 
access or right to the permitted lands should be included in calculating the value of the fee-simple lands condemned. The lower courts argued that the value of access to the permitted lands should be included, following the decision in a prior condemnation case involving access to grazing lands. The Supreme Court overturned this decision, ruling that the government should not compensate landowners for value "given" by virtue of ongoing government action. Citing several cases regarding condemnations along navigable waters, the court concluded that "If...the government need not pay for value that it could have acquired by exercise of a servitude arising under the commerce power, it would seem a fortiori that it need not compensate for value that it could remove by revocation of a permit for the use of lands that it owned outright" (p. 492). In this decision, the court formed a "working rule" that value-added by completed government works projects is not exempt from compensation, whereas value added by revocable benefits such as grazing permits is exempt. The court cited the TGA in noting that "no compensable property right [is] created in the permit lands themselves as a result of the issuance of the permit" (Fuller, p. 494).

The dissent in Fuller is worth reviewing both because it echoes some of the arguments of the pro-private rights advocates and because the case was decided on a 5-4 margin. Writing on behalf of the court's more liberal members, Justice Powell noted that grazing permits are of "considerable value" to ranchers. The dissenting Justices agreed with the actions of the lower court in considering the value of the permit in the condemnation action. If all the grazing land had been removed from grazing use at the same time as the condemnation, however, the dissenters would have agreed that compensation for the value of the permit would no longer be justified.

The cases noted above make it difficult to maintain the existence of private property rights in public lands on a legal basis. On numerous occasions, the courts have stated that grazing permits are not a "vested right" under the law and give no compensable interest in the land. Nevertheless, private-rights advocates such as Hage and Budd-Falen remain convinced of their legal arguments. In the wake of Fuller, for example, Falen and BuddFalen make several points that must be considered. The first is the familiar argument that Fuller, like all cases cited here, dealt only with permit rights rather than the preference rights underlying them. The second is that the government only condemned part of Fuller's base property and that the plaintiff therefore never lost his grazing right and was due no compensation in any event. Third, Falen and Budd-Falen raise the taxability of grazing rights as firm evidence that a grazing preference is a property right. Finally, Hage's argument based upon western water law and grazing as a beneficial use remains to be considered.'

A review of these private property rebuttals reveals a number of difficulties, some already touched upon in the preceding paragraphs. Taking the preference versus permit issue first, this article has already shown how Hage's view of the distinction is not supported by much of the language in the TGA or U.S. Code. Falen and Budd-Falen (1993, p. 510) cite several subsequent cases to

\footnotetext{
Careful readers will note that the article has skipped Hage's argument about the Department of Defense recognizing grazing permits as a property right. This point turns out, however, to be an exception that proves the rule. In Obsome v. U.S., 145 F.2d 892 (1944), the court noted that the history of the TGA clearly indicates the World War IIera amendment regarding payment for DOD condemnations of grazing land is needed precisely because such actions are not normally compensable. If compensation were normally due, the specific TGA amendment for DOD actions would be redundant.
}

support the claim that "prior rights or uses in the federal lands have been [legally] recognized." The first is McNeil v. Seaton (281 F.2d 931 (1960)), in which a permittee (McNeil) sued to prevent loss of his grazing privileges due to changes in the rules of eligibility made by the Secretary of the Interior for his grazing district. Falen and Budd-Falen (1993, p. 510) claim that the decision acknowledged "once a preference right is established, the permittee is entitled to rely on it." The case does take a relatively pro-rancher stance, citing Red Canyon and the TGA to indicate that ranchers have some form of "rights" under the act and that the Secretary has an "affirmative obligation" to safeguard such grazing privileges. The preference right noted, however, is only against other potential competitors for the grazing permit (See also Coggins and Glicksman 1995, \$19.02). It is not, and could not, be against the government itself-such a right to a permit does not legally exist. As the court itself noted-"It is clear...the Government for its own use may without payment of compensation withdraw the permit privilege (McNeil, p. 934, citing U.S. V. Cox 190 F. 2d 293 (1951))." Thus, Falen and Budd-Falen's view is technically correct but obscures the more general point of the McNeil court-a rancher can rely on a preference right against other potential graziers only at the continued sufferance of the federal government.

A second case relied upon by Falen and Budd-Falen is Choumos v. United States (193 F.2d 321 (1951)). Another case from the Tenth Circuit Court of Appeals (whose judges are, according to McNeil, "thoroughly familiar with the problems of the range"), Chournos involved a complicated dispute between an owner of lands checkerboarded between public domain managed by the BLM. The rancher temporarily lost his grazing permit to the public domain interspersed within his lands, and sued for damages after the permits were finally issued. Falen and BuddFalen cite the definition of the "purpose" of the TGA from the decision, that purpose being "to stabilize the livestock industry and to permit the use of the public range according to the needs and the qualifications of the livestock operators with base holdings" (Chournos, p. 323). Falen and Budd-Falen do not note that the court found for the government in this case, stating that the rejection of the rancher's application was within the "discretionary function" of the BLM and merited no damages.

Although these 2 cases (following Red Canyon) do recognize the value of a permit and a preference to permittees against other ranchers based on their prior use of the land, at no time does any court challenge the basic premise that these grazing rights are revocable at any time without compensation. Nor does the TGA provide any clear indication of making this distinction between permit rights and prior rights in the land. Indeed, in another federal decision on grazing rights the courts explicitly rejected the "preference right" line of argument. "It is safe to say," wrote the court in Osborne v. U.S. (145 F.2d 892 (1944)), "that it has always been the intention and policy of the government to regard the use of its public lands for stock grazing, either under the original tacit consent or. . under regulation through the permit system, as a privilege which is withdrawable at any time for any use by the sovereign without the payment of compensation." As candidates for status as fully vested, compensable property rights, both grazing permits and preference rights come up short.

Leaving Falen and Budd-Falen's technical second point about the Fuller decision to a footnote, this review will next consider their observations regarding the IRS determination of grazing 
permits as a taxable form of property. ${ }^{2}$ The property rights advocates offer a 1955 Tax Court decision (Shufflebarger v. Commissioner, 24 T.C. 980) as one of their strongest pieces of evidence. "Because the preference is not created by the federal government, but rather is bought and sold by private individuals, the Internal Revenue Service determined that the preference is, in fact, a property right" (Falen and Budd-Falen 1993, p. 511) A review of this case and supporting tax law and rulings is clearly required.

In Shufflebarger, the claimants argued that their preference right to grazing land has value only for the 8 years of the grazing permit and is therefore depreciable for tax purposes. The tax court found otherwise, observing that most permits are renewed indefinitely even while the government retains the formal option of canceling them at any time. In a footnote, the court made explicit its understanding of the difference between a permit and a preference. Permits are given to applicants who have "established preferences" which give the holder "special consideration over other applicants who have not (Shufflebarger, p. 981)." These preferences, the court noted, convey "no legal right to the use of [the]. . range." A preference is a "thing of value," and therefore subject to taxation as "property" according to the IRS. A later IRS ruling \#86-99 (as well as several intervening cases) affirmed this conclusion with respect to taxation of the value of a grazing permit for estate taxes, calling it "a valuable asset." Such a view does not disagree with the decisions reviewed in this essay several of which note that a grazing preference right or permit is a thing of value. The IRS views such value as "property" for purposes of taxation. However, the IRS makes no stronger claim for the rights inherent in a grazing preference than the other courts noted herein. The Shufflebarger decision may encourage privaterights advocates by using the word "property" in conjunction with a grazing preference, but it is clearly a very different kind of property than the vested, compensable property rights Falen and Budd-Falen have in mind.

Finally, one must consider Hage's argument that grazing is a beneficial use appurtenant to an appropriative water right, and therefore a form of private property as well. In many respects, this argument may be the private-rights advocates' most successful foray into the legal arena. At least 1 previous case has held that "arbitrary and capricious" regulations by federal agencies on public lands may create a taking of private water rights (Fallini $\mathrm{v}$. Hodel, 725 F. Supp. 1113 (1989)). More recently, the U.S. Court of Claims is hearing arguments in Hage's own lawsuit regarding an alleged taking of private water rights through reductions or cancellations of federal grazing permits (Hage v. U.S., 35 Fed.Cl. 147 (1996)). The argument in that case, as readers may recall, is that grazing federal lands is a "beneficial use" upon which the private water right depends. Remove the grazing permit, and one effectively removes the water right. Thus, the permit is not itself a form of private property (which argument has explicitly been rejected by the Hage $\mathrm{v}$ U.S. . court, following precedent cited in this essay), but its removal may lead to a compensable taking of private property in the form of an appropriative water right.

There are several possible counter-arguments to the water

\footnotetext{
The response to Falen and Budd-Falen's second point (that Fuller did not lose all his base property and therefore failed to lose his grazing right), is only that this may be true (the record is silent) but the distinction makes little difference to the general principle announced by the Supremem Court that such a loss would not be eligible for compensation in either case.
}

rights claim. First of all, even an appropriative water right is a usufructuary one, providing the right to use the water but not to "own" the resource in the same manner as title in fee-simple. ${ }^{3}$ More importantly, it seerns unclear that a beneficial use such as grazing is somehow a protected private property right because it happens to be part of the justification for a water right. At least 1 recent court decision has found "no support" for such an argument regarding grazing rights in the case law presented (Fulton v. U.S., 825 F.Supp 261 (1993)). Does a farmer have a "property right" to irrigate his land, one might ask, just because his appropriative water right depends on this activity? Furthermore, because federal law generally preempts state law on the public domain, and the federal legal right to withdraw a grazing permit is apparently undeniable, it is hard to see how a state water right could overrule this federal action on federal land. To argue otherwise is to claim, in effect, that the tail wags the dog.

In considering the water-rights argument, it is also important to remember that no court has yet found in favor of Hage's claim the recent Hage $v$ U.S. ruling was only a denial of the government's motion for summary judgment on that point. Nevertheless, the water rights challenge may be the most likely to succeed in court exactly because it is furthest removed from a basic claim of private property in a grazing permit, preference, or permitted land itself. In the Fallini case, for example, the determination of a taking of private property was due to the diminution of value at a specific watering site following excessive BLM regulation for wild horse and burro access. There was no consideration of the rancher's grazing permit or preference right to graze the land. Similarly, the Hage v U.S. case could eventually find a taking of Hage's water rights on public lands - but such a finding is significantly different than supporting a vested property interest in the grazing permit or the land itself. Under the water-rights argument, for example, any permit-losing rancher lacking a vested water right on public lands would still be out of luck.

Whether one sees a grazing right as a form of "property" depends ultimately on the view of property one has. Falen and Budd-Falen (1993, p. 505) cite a 19th Century Supreme Court decision in defining the contested term as embracing "all valuable interests which man may possess outside of. . his life and liberty." Quoting from the dissent in that case, Falen and Budd-Falen do not entirely convey what the minority opinion in Campbell v. Holt (115 U.S. 620 (1885)) was trying to say. "The term "property'," said the dissent, ". . . is not confined to mere tangible property, but extends to every species of vested right" (Campbell, $p$. 630). But if property as relevant to the Fifth and Fourteenth Amendments covers all "vested rights," it does not cover grazing preferences or permits, both of which the courts have regularly declared not to be a kind of "vested right." The case law does, however, support a "thing of value" view of property for grazing permits as outlined by the Red Canyon court and the IRS in Shufflebarger and other rulings. Such a view acknowledges the clear financial advantages of a grazier's preference right against other ranchers, while stopping short of declaring that preference a vested right of private property, protected from uncompensated government action. But what does this legal hair-splitting mean

\footnotetext{
3 The Hage v. U.S. court rejecled this argument, however, concluding that appropriate water rights are full property rights, "entitled to the full protection of the Constitution" (Hage v. U.S. p. 172). This view diverges from the opinion in Red Canyon cited earlier, which took a weaker stance on water rights as a form of protected private property (see discussion earlier in article).
} 
for ranchers and federal land managers? Legal precedent aside, how might all sides better talk about the conflict? That is what the "imaginative lenses" of the next section of the article will attempt to reveal.

\section{Seeing Property, Seeing Permits-Some Alternative Views}

Following Rose (1994), this section will begin by looking at a couple of standard common law notions. It is an old principle of the law that first possession is the root of all title. This idea, of course, immediately raises the question of what counts for "first possession" (Rose 1994). The idea of first possession is an important part of Hage's argument for property rights in grazing preferences based on the maxim "first in time, first in right." But the common law doctrine cited by Rose actually exposes a basic practical problem within the rancher's case. First possession of 160 acres of farmland or a productive mining claim is relatively easy to establish. One can grow crops, build fences, install irrigation systems and generally occupy the land in an intensive manner. Possession of thousands of acres of grazing forage is more difficult to establish (stock ponds and salt licks to the contrary), especially when the government is unclear on the amount of acreage needed in the arid west to maintain a viable family ranch. In this respect, the law prohibiting fencing on the public domain in 1885 was a blow to ranchers hoping to support a claim to property rights through the first possession doctrine.

The nature of ranching in the arid west also resists the Lockean philosophy of ownership underlying the common law. For Locke (1690), the right to property arises from a "mixing" of one's labor with the items owned-what you work with is what becomes your property. This philosophy underwrites the ideal of the small farmer as propagated by the federal government through the Homestead Act and other efforts to support small private claims to land. It is harder to reconcile a Lockean notion of ownership with the grazing of hundreds of cattle on thousands of acres of open land, especially when those cattle are sometimes left untended for long periods. This is not to say that ranching is not as hard or harder work than farming-by all accounts such a claim would be absurd. The point is that the act of grazing in the arid west is more removed than crop farming from Locke's basic image of mixing one's personal sweat with each acre of the soil to make it one's own. Tangible evidence of labor on grazing lands (in the form of fencing, watering holes, or other improvements), is less obvious to the untrained eye than on a commercial farm with its large combines and orderly rows of crops. Furthermore, government policy towards homesteading and private land ownership consistently suffered from this "Lockean bias"-rejecting appeals (by John Wesley Powell and others) for a policy of larger homesteads on arid lands in favor of the traditional 160 acres plot and the travails of "dry farming." Ranchers in part have had a difficult time gaining ownership of grazing lands because of this Lockean bias.

A second common law doctrine relevant to grazing rights is that of "adverse possession." Rose (1994, p. 15) explains the idea as a "transfer" of property from "the title owner to another who is essentially a trespasser, if the trespasser's presence is open to everyone and lasts continuously for a given period of time, and so long as the title owner takes no action to get rid of him during that time." Ranchers such as Hage clearly use this type of reasoning in their property claims without specifying it by name. "The continued inaction of Congress", Hage (1989, p. 151) writes, "[to disavow the rancher's grazing rights on public lands] was viewed by westerners as a clear signal that the stockmen's land claims would eventually be.. .honored." While claims of adverse possession against government property are often restricted or prohibited by law (Powell, 1968, p. 1099), there is nevertheless some validity to this idea-the history of American settlement has often seen the recognition of previously illegal occupations of public land as later rights to title. Indeed, under the TGA, rights to grazing permits were established in part by existence of fencing and other improvements to the public domain prior to the act's passage. Nevertheless, in the ranching case the government did take some action against users of the public lands, noting in plain language on several occasions (Buford. Light, et al.) that use of the range was not a prelude to any sort of permanent property right. These decisions may not have physically removed ranchers from public lands, but they did clearly contest any claims of land ownership by parties other than the government.

Robert Nelson (1986) makes a different case for grazing permits as a form of private property. His view is that grazing permits are an example of Charles Reich's (1964) "new property" in government actions, following a pattern similar to the privatization of other formerly public efforts. Nelson (1986, p. 364) writes that "government has seldom succeeded when it has sought directly to 'privatize' a publicly owned or common property resource. By indirect routes, however. . .government has created many new private property rights in publicly owned resources." Nelson (1986) outlines 4 stages in the privatization process: (1) government grants new rights; (2) dominant users gain hegemony over how to administer those rights; (3) users become able to sell or otherwise "alienate" their rights; and finally, (4) government formally transfers the rights to the users and ceases regulation. Grazing permits are an example of a public action that has reached the third stage of "privatization"- transferability on the open market by users. They are, according to Nelson (1986, p. 369), "virtually a form of private property." Nelson (1986) notes the similarity between grazing permits and other forms of marketable "new property": broadcasting rights, rights to raft on public rivers, air pollution rights, and even in some cases zoning rights. It is important to keep in mind that in most of these examples, the government never intended for these rights to become private or quasi-private. And yet it keeps happening.

The idea of "new property" resonates with the "thing of value" view of grazing permits found in the courts. And Nelson's placement of the grazing permit in a more general category of similar "quasi-properties" adds depth to his argument. His view avoids the polar extremes of "private versus public" rights and in so doing brings a much-needed addition of complexity to the discussion. Rights are not simply public or private-they often take on aspects of both realms simultaneously. Of course, Nelson thinks that grazing permits have become almost entirely private rights at this point, which is overstating the case. Permits can be (and have been) revoked without compensation at the government's discretion-hardly an indication of a fully-private or even nearly-private right. Nevertheless, it is clear that any discussion of grazing rights must encompass a continuum of "privateness" rather than a binary "public or private" system in order to advance the issue.

Another provocative point raised by Nelson's piece is the experience of the Reagan administration in proposing to sell portions of the public domain in 1982. According to Nelson (1986, p. 373), "virtually every user of the public lands opposed this idea." The opposition included public lands ranchers. The reason for this, asserts Nelson (1986, p. 373), was that all of these users considered themselyes as "holders of vested rights to continue exist- 
ing land uses." This should come as a surprising statement to careful readers of the legal review in this article. Therein, it was noted that the courts repeatedly declared no "vested rights" to grazing or other uses of the public lands existed by law. Why, then, was the Reagan administration unable to sell the public lands even with the weight of the law behind them? In one sense, despite the legal precedent to the contrary, the government was unable to sell the lands because, as Nelson (1986, p. 373) says, "it did not really own them."

What is Nelson claiming here? To answer this fully, one needs to use another lens crafted by Robert Ellickson (1991) in his study of ranching in Shasta County, California. "Legal rules," writes Ellickson (1991, p. 40), "hardly ever influence the settlement of cattle-trespass disputes in Shasta County." This is true in the case of fencing disputes as well. What governs actions instead of written law are norms of behavior as worked out within the community-few residents even have any idea what the law says about the issue at hand. What is more interesting is that in cases where the law does have a significant role, local residents still misunderstand the rules. In vehicle-cattle collisions, for example, Ellickson's ranchers have a simple belief based on the difference between "open" (i.e. "fence out") and "closed" (i.e. "fence in") range: in an accident on open range, the "driver buys the cow"; on closed range, the situation is reversed and the "rancher buys the car." This belief is legally incorrect, at least in Shasta County. The law does not care whether an accident occurs on open or closed range-it only cares about the potential negligence of either party involved. Several high-profile cases have been decided within the county against the ranchers' idea of the open/closed range distinction. At least 1 case cost an under-insured rancher $\$ 100,000$ out-of-pocket in damages. And yet, local ranchers are more confident than ever that "the legal specialists, not they, are the ones ignorant of the governing legal rules" (Ellickson 1991, p. 103).

Nelson and Ellickson are describing a common phenomenonone mirrored in the efforts of Hage and others like him. This phenomenon is the assertion of rights (property and otherwise) in the face of clear judicial and statutory evidence to the contrary. How can this happen? Part of the answer lies in the marginal value of law and the legal system to most of society. "Law is not central to the maintenance of social order" concludes Ellickson (1991, p. 280)--social norms and custom are. Therefore, the law often does best when it simply ratifies existing custom and social norms, rather than trying to go against the grain. This belief echoes Hage's comments quoted earlier about the value of custom and historical practice on the western range as the basis of property rights. What Ellickson and Nelson demonstrate with their examples is that norms and custom often win the battle with laws over the definition of ideas and beliefs. What the law says may be ignored as irrelevant by those relying on a different system of justice. Some ranchers believe they are not liable for accidents on the open range because they have always believed that. Similarly, traditional users of the public lands believe they have a "vested right" to those uses in spite of clear legal evidence to the contrary. The more the law tries to fight these deeply-held beliefs, the more unrest that occurs. As Ellickson (1986, p. 286) puts it, "lawmakers who are unappreciative of the social conditions that foster informal cooperation are likely to create a world in which there is both more law and less order."
What is most striking about this incongruity between law and custom is how often custom wins. The experience of the Reagan administration is a perfect example. Legally, no public lands user appears to have demonstrated in court the "vested rights" they claim. Despite this, the proposal to sell selected tracts of public land was sunk by the lobbying of groups who believed they had these rights by custom. And in winning this battle, the groups demonstrated that in one sense they do have these vested rightsif only in the political rather than the judicial arena. Similarly, the arguments of rancher-advocates such as Hage, Falen, and BuddFalen generally fail in the judicial realm but have succeeded repeatedly in the political process, as demonstrated by their continuing victories over adversaries and would-be regulators. Nelson (1986) is absolutely right-in one important sense, users such as ranchers own the public range. The Reaganites tried to sell something that through custom was no longer theirs, even if they retained legal title.

The relevance of custom to property rights comes more sharply into view with consideration of the public trust doctrine. The idea of the public trust is one of inalienable rights of the public in certain common properties that the government cannot alienate or otherwise dispose. The doctrine focuses on a public trust in navigable waterways for commerce purposes, although lately that application has been broadened to include recreation and other rights in waterways and beaches (See Sax 1970 for an excellent review). According to legal theorists, the notion of the public trust stems from the authority given to customary uses of land or property in common law. "The medieval customary law," declares leading public trust scholar Joseph Sax (1980), "had the striking advantage of putting developed expectations, rather than formalities such as title ownership, at the center of attention." The same is true of the public trust - the clearest example from case law being Illinois Central Railroad v. Illinois (146 U.S. 387 (1892)) which found that just because the government nominally owned the Chicago waterfront did not mean they could sell the entire harbor to the local railroad. Customary use of this resource by the public trumped the legal powers of the legislature and prevented the sale.

In his public trust discussion, Sax (1980) particularly emphasizes the importance of expectations and custom in property law. "The central idea," he writes of the doctrine, "is preventing the destabilizing disappointment of expectations held in common but without formal recognition such as title" (Sax 1980, p. 188). His proposal is that expectations should carry more weight than "mere title" in many environmental and other natural resource disputes. Although Sax's agenda is clearly to expand control of the government over fee-simple property owners, his work has a surprising and important implication for the analysis herein. Certainly, Hage would argue that rangelands are a case where, to use Sax's (1980, p. 193) words, "title and expectations are not congruent." But in these cases, Sax (1980) urges his readers to give less consideration to title and favor expectation instead. Thus, the public trust doctrine (à la Sax) appears to support the private rights in public lands claim based on customary use.

There arc clearly differences between the arguments based on custom made by Sax on the one hand and Hage on the other. Sax is lobbying on behalf of the customary public use of private lands, whereas Hage is arguing the opposite. Nevertheless, the value of the Sax article for our purposes is its ratification of the importance of custom in social order and property systems. We 
hear the echoes of Ellickson when Sax (1980, p. 193) writes that the courts failure to recognize "expectations in ways that minimize destabilization of expectations could represent a failure to act for a public purpose." Hage can then reply to this by saying that one cannot have it both ways-if customary use of private lands confers property rights, then so should customary use of those properties owned in title by the government. To act otherwise in either case is to destabilize expectations at the expense of the public purpose.

\section{Conclusion-A Threat to our Common Property}

Rose $(1994$, p. 5) observes that private property regimes are themselves a sort of common property-one held together "only on the basis of common beliefs and understandings." To "own" something a person must provide "notice to the world" that it is her own in a manner that is understood by those around her. This communication must be ongoing to be effective-owners must speak and "keep on speaking" through whatever methods are culturally recognized in order to maintain their property rights. Sometimes these methods of communication will be through the law. Other times, as we have seen, they will not. In either case, the crucial aspect of ownership becomes convincing or persuading others that one has a property right under a mutually understood property regime. This is the basis of all property systems for Rose, and the idea behind the title of her book.

In the case of grazing rights, the dialogue of persuasion seems to be going on at 2 incompatible levels. Legally, as was shown in this review, the judiciary is telling ranchers in fairly certain terms that they own no vested or absolute private rights to or in the public lands. The graziers' claims also are challenged by public perceptions of the common law doctrine of first possession and the Lockean theories behind it. Culturally, on the range and in the legislature, the conversation is very different. Ranchers and other users of the public lands are telling themselves and anyone who will listen that they are the true owners of rights in the public domain. Basing their arguments on customary use, they follow their brethren in Shasta County by refusing to be persuaded by legal opinions to the contrary. The power of norms and custom over law in this dialogue should not be underestimated-even the common law idea of the public trust as promulgated by an environmentalist such as Joe Sax relies on the power of customary use over "mere title."

Rose (1994, p. 296) sounds a note of caution at the end of her book: "property regimes cannot bear very many or very frequent uses of force; force and violence are the nemesis of property, and their frequent use is a signal that a property regime is faltering." If the events of the last few years are any indication, the property regime of the western grazing lands is very much under attack. Public range managers and users are faced with 2 groups who are speaking without hearing, listening without understanding, and failing on both sides to be persuaded. The "cultural limitations" on imagination cited by Rose in the opening quotation are in fullforce. What should be done?

A difficult but essential first step is to broaden the views of the parties involved. Jurists, administrators, and their supporters need to realize that court decisions and legal precedents sometimes carry much less strength than they might imagine. The persuasion process merely starts with a legal decision rather than ending with it. As many organizational theorists have noted, the authority of a rule lies in its acceptance by the subordinate rather than the rule-maker (Barnard, 1938). Similarly, ranchers and private- rights advocates need to acknowledge the relative weakness of their legal case and move on, rather than continuing to press for victory in a battle that has already been mostly fought and lost. Their case is better made in the political and cultural realm, within the confines of current legal realities. At the risk of sounding naive, both sides need to see the world from another point of view. They need to use their "imaginations," as Rose (1994, p. 297) urges, and realize that "what you see in property is what you and others have talked yourself into about those 'things'." What will happen if either side is able to see things from another point of view is beyond prediction, but that it would be an improvement on the current situation seems clear. To truly understand another's view requires a basic level of respect that brings with it a world of potential for resolution. As Rose (1994, p. 297) concludes, "given some imagination, you may always talk yourselves into seeing something else-with all the effects on understanding and action that a new 'envisioning' may bring." That is precisely the point of this essay-to bring a little imagination to the problem of property in grazing rights, so that at some point everyone might be speaking of the same thing.

\section{Literature Cited}

Barnard, C.A. 1938. The Functions of the Executive. Harvard Univ. Press, Cambridge, Mass.

Boyer, R., H. Hovenkamp, and S.F. Katz. 1991. The Law of PropertyAn Introductory Survey (4th ed.). West Publications, St. Paul, Minn.

Coggins, G. and R. Glicksman. 1995. Public Natural Resources Law. Clark, Boardman, and Callaghan Press, Deerfield, $\mathrm{IL}$.

Ellickson, R. 1991. Order Without Law: How Neighbors Settle Disputes. Harvard Univ. Press, Cambridge, Mass.

Falen, F.J., and K. Budd-Falen. 1993. The Right to Graze Livestock on the Federal Lands: The Historical Development of Western Grazing Rights. Idaho Law Review 30:505-524. Ida.

Hage, W. 1989. Storm Over Rangelands: Private Rights in Federal Lands. Free Enterprise Press, Bellevue.

Locke, J. 1690. Two Treatises of Government. ed. Peter Laslett. Cambridge University Press, Cambridge, U.K.

Nelson, R.H. 1986. Private Rights to Government Actions: How Modern Property Rights Evolve. University of Illinois Law Review 1986-2:361-386.

Powell, R.R. and P.J. Rohan. 1968. Powell on Real Property, (abridged version). Matthew Bender Press, N.Y.

Reich, C. 1964. The New Property. Yale Law Journal 73:733-787. Conn.

Rose, C. 1994. Property as Persuasion: Essays on the History, Theory, and Rhetoric of Ownership. Westview Press, Boulder, Colo.

Sax, J. 1970. The Public Trust Doctrine in Natural Resource Law: Effective Judicial Intervention. Michigan Law Review 68:471-566. Mich.

Sax, J. 1980. Liberating the Public Trust Doctrine From Its Historical Shackles. U.C. Davis Law Review 14:185-194. Calif. 